\section{Shuttle Diplomacy Indonesia di ASEAN Terkait Konflik Laut Tiongkok Selatan}

\section{Muhammad Naufal Aziz}

Universitas Andalas

Naufalaziz18@gmail.com
Frequency of International Relatio

Vol 1 (1) 37-78

(C) The Author(s)

fetrian.fisip.unand.ac.id

Submission track :

Submitted : January 18 th 2019

Accepted : July 29th, 2019

Available On-line : July 29th 2019

\begin{abstract}
This research aim to analyze the succeeding factors of mediation inside the Shuttle Diplomacy that is conducted by Indonesia for two days in bringing together ASEAN countries voices after a deadlock on the 45th AMM meeting in Cambodia. Researchers refers to Lawrence Susskind and Eileen Babbitt works to explain why a mediation effort could work effectively, namely with the awareness of not carrying out unilateral actions, drafting alternative agreements to avoid ongoing conflict, delegates in negotiations are people who have authority and are committed in implement agreed actions, external factors that force the parties to seek a conflict resolution, the mediator is someone who could be accepted by all parties. This is a qualitative research with descriptive analysis methods to find the answers what makes shuttle diplomacy that is conducted by Indonesia could be working effectively. This research found that the mediation could be effective because there is awareness of each ASEAN country not to carry out unilateral actions towards the conflict, Marty Natalegawa proposed the Six Point Principle on the South China Sea draft as an alternative to communique that has failed before and ensured this agreement is obeyed by all parties, Indonesia's role as mediator and the existence of other international interests also forcing ASEAN countries to determine a common perspective towards South China Sea conflict.
\end{abstract}

Keywords : Indonesia; South China Sea; Shuttle Diplomacy; Mediation 
Muhammad Shuttle Diplomacy Indonesia di ASEAN Terkait Konflik Laut

Naufal Aziz Tiongkok Selatan

\section{Pendahuluan}

Permasalahan Laut Tiongkok Selatan (South China Sea) telah dimulai sejak pemerintah Tiongkok di bawah rezim Zhou Enlai mengklaim kedaulatan mereka atas pulau Spratly dan pulau Paracel pada tahun 1951 ketika terjadi negosiasi perjanjian damai dengan Jepang (Pravel 2011, 2). Tiongkok mengajukan klaim yang berdasarkan pada prinsip "Historic Waters" atau wilayah perairan yang menjadi yurisdiksi Tiongkok berdasar sejarahnya.

Klaim yang dibuat oleh pemerintah Tiongkok tersebut mendapat pertentangan oleh beberapa negara yang berada di wilayah Laut Tiongkok Selatan. Taiwan, mengklaim Paracel dan Spratly sebagai bagian teritorinya dengan alasan historis yang sama. Sementara Vietnam membuat klaim mutlak tentang kedaulatannya atas Kepulauan Spratly yang mencakup laut teritorial, zona tambahan, Zona Ekonomi Ekslusif, dan landas kontinen berdasarkan argumen wilayah "warisan kolonial Prancis". Pernyataan ini juga didukung dengan adanya dokumen resmi yang berjudul Limits in the Seas (Bureau of Inteligence and Research of US Department, 1977).

Filipina menyatakan klaimnya atas dasar kedekatan geografis, keamanan nasional, okupasi efektif, dan kontrol serta ketentuan hukum dari ZEE, meskipun klaim Filipina dianggap lemah (hanya berdasar klaim bahwa pelaut Filipina menemukan beberapa kepulauan di barat spratly pada tahun 1956) dan tidak didukung dengan adanya 
Muhammad Shuttle Diplomacy Indonesia di ASEAN Terkait Konflik Laut Naufal Aziz Tiongkok Selatan

bukti yang solid dalam hukum internasional atas kepulauan Spratly. Malaysia mengklaim kepemilikan atas 12 pulau yang berada di kawasan kepulauan Spratly, Malaysia juga mengklaim 200 mil ZEE dari garis pantainya, hal yang sama dilakukan oleh Brunei (Sichun, 2013).

Tumpang tindih klaim atas kawasan laut Tiongkok Selatan terus berlanjut hingga tahap konflik bersenjata. Pada tahun 1994 terjadi konfrontasi bersenjata antara Tiongkok dan Vietnam di perairan Tu Chinh blok 133,134 dan 135 dimana Vietnam berpendapat wilayah tersebut adalah wilayah perairan internasional dan mereka memiliki hak untuk mengadakan kegiatan eksplorasi sementara Tiongkok men gklaim bahwa wilayah tersebut adalah milik mereka (Sudira 2015, 148150). Lalu pada tahun 1995 Tiongkok menuduh Filipina mencuri karang dan Filipina membalas dengan menyerang orang-orang Tiongkok. Di tahun yang sama, pasukan artileri Taiwan menyerang kapal suplai Vietnam. Dari Tahun 1996 hingga 1999 terjadi serangkaian kontak senjata antara Tiongkok dan Filipina berlanjut hingga tahun 2002 (Sudira, 2015).

Menimbang konflik laut Tiongkok Selatan yang berpotensi mengganggu kestabilan di kawasan, ASEAN sebagai organisasi di kawasan yang terkait sudah melakukan serangkaian usaha-usaha untuk meredam terjadinya konflik lebih lanjut. Pada tahun 2002 diinisiasi sebuah kesepakatan antara negara-negara ASEAN dan 
Muhammad Shuttle Diplomacy Indonesia di ASEAN Terkait Konflik Laut

Naufal Aziz Tiongkok Selatan

Tiongkok yaitu The Declaration on the Conduct of Parties in the South

China Sea (DOC). Dalam DOC disepakati bahwa negara anggota ASEAN terutama Vietnam, Filipina, Malaysia, Brunei Darussalam, serta Tiongkok berkonsolidasi serta memperbaiki kembali hubungan yang sempat menegang akibat konflik perebutan wilayah.

Pihak-pihak yang terlibat di dalam deklarasi tersebut harus memiliki komitmen untuk melakukan afirmasi kembali terhadap Charter PBB dan UN Convention on the Law of the Sea 1982, TAC, dan berbagai hukum internasional lainnya yang mengakui prinsip-prinsip hukum internasional yang mengakomodasi hubungan antar negara.

Namun, DOC ini dinilai kurang efektif dalam misinya untuk membentuk rasa saling percaya diantara pihak yang berkonflik dan untuk mencegah permasalahan berkembang menjadi lebih jauh. Kesepakatan yang terjalin di dalam DOC dipandang lemah karena hanya memberikan batasan-batasan moral dalam menangani konflik yang ada, lalu dokumen DOC juga tidak mempunyai mekanisme untuk memonitor bahkan untuk memaksa negara-negara yang terlibat mematuhi dokumen yang sudah disahkan. Hal yang paling krusial adalah tidak adanya sanksi yang jelas jika terjadi pelanggaran ( $\mathrm{Li}$, 2014).

Beijing juga menanggapi perjanjian ini dengan cara yang berbeda dan memilih untuk menyelesaikannya dengan cara bilateral seperti yang disampaikan oleh Xue Hanqin, Duta Besar Tiongkok untuk 
Muhammad Shuttle Diplomacy Indonesia di ASEAN Terkait Konflik Laut

Naufal Aziz Tiongkok Selatan

ASEAN pada forum the Institute of Southeast Asian Studies di

Singapura: (Hanqin 2010, 45-46)

In the follow-up negotiations on the draft guidelines for the implementation of the DOC (Declaration on the Conduct of Parties in the South China Sea), the work got stuck mainly because of the difference over the modality of their (ASEAN member-states) consultations. The key issue is whether ASEAN Member States should consult among themselves first before they consult with China. ASEAN members insist on such a consensual approach towards China, while the Chinese side does not think this is in line with the understanding of DOC. The whole issue of South China Sea is not a matter between ASEAN as an organization and China, but among the relevant countries. ASEAN could serve as a valuable facilitator to promote mutual trust among the Parties, but not turn itself into a party to the dispute.

Penyelesaian konflik melalui jalur bilateral seperti yang Beijing kehendaki dianggap hanya akan menguntungkan Tiongkok yang dapat mendesak negara-negara yang terlibat untuk menyetujui apa yang diinginkan oleh mereka mengingat negara Tiongkok yang bertatus sebagai negara adidaya dan tidak adanya kekuatan yang sebanding dari negara-negara di ASEAN (Ba 2014, 2-3). Penyelesaian konflik secara multilateral dianggap lebih pas untuk mengimbangi kekuatan Tiongkok tersebut ditambah dengan hadirnya ASEAN sebagai penengah akan memberikan hasil perundingan yang lebih adil.

Sebagai salah satu negara yang berada di kawasan ASEAN dan dekat dengan Laut Tiongkok Selatan, Indonesia sebenarnya menolak untuk disebut sebagai negara pengklaim yang bersengketa di dalam konflik ini, namun tentu saja Indonesia juga memiliki kepentingan di dalamnya. The nine dashed line atau 9 garis putus-putus yang dibuat 
Muhammad Shuttle Diplomacy Indonesia di ASEAN Terkait Konflik Laut

Naufal Aziz Tiongkok Selatan

oleh pemerintah Tiongkok berbatasan langsung dengan wilayah terluar Indonesia, yaitu kawasan Laut Natuna. Hal ini juga diprediksi dapat menimbulkan konflik di kemudian hari karena wilayah laut tersebut yang merupakan wilayah Kedaulatan ZEE Indonesia menyumbang sebanyak 30 persen dari pendapatan migas Indonesia (Sandi 2013).

Terlebih potensi di sektor perikanan yang ada di wilayah tersebut mengundang kapal-kapal nelayan asing untuk melakukan kegiatan perikanan secara illegal, salah satu pelanggaran yang sering terjadi adalah aktivitas kapal nelayan Tiongkok yang mengklaim wilayah Laut Natuna masih merupakan wilayah perairan mereka (Welle 2016). Lalu, sejak Orde Baru Indonesia mengasosiasikan diri sebagai negara berkembang yang perlu menjaga kestabilan di kawasan sekitarnya dan menghilangkan ancaman potensial yang dapat mengganggu laju pertumbuhan ekonomi di dalam negeri (Aplianta 2015, 8).

Sikap Indonesia di dalam Konflik Laut Tiongkok Selatan juga terus mengalami perubahan dari waktu ke waktu. Awal keterlibatan Indonesia didalam konflik Laut Tiongkok Selatan pada era Orde Baru (sekitar tahun 1980), dengan kondisi hubungan diplomatik yang masih "beku" dengan Tiongkok, Indonesia menggunakan pendekatan yang tradisional terhadap konflik yaitu dengan mengirimkan kekuatan militer ke daerah perbatasan di Natuna, hal ini dianggap wajar karena 
Muhammad Shuttle Diplomacy Indonesia di ASEAN Terkait Konflik Laut

Naufal Aziz Tiongkok Selatan

ketika itu pemerintahan Indonesia lebih fokus pada masalah perbatasan dan territorial (Aplianta, 2015).

Setelah terjadinya normalisasi hubungan diplomatik dengan Tiongkok, dan keterlibatan Tiongkok yang lebih aktif didalam forumforum ASEAN, Indonesia perlahan mengubah sikap dan mulai mengakomodasi perundingan. Sebagai contoh sejak tahun 1990 Indonesia secara aktif menjadi inisiator sekaligus fasilitator agar terciptanya lokakarya yang bernama The Workshop on Managing Potential Conflict in The South China Sea yang mempertemukan semua negara pengklaim kepulauan spratly dan bertujuan untuk memberikan pandangan dan saran secara teknis dalam proses negosiasi, lokakarya ini juga bertujuan untuk menanamkan rasa kepercayaan dan pemahaman yang lebih diantara pihak yang bertikai (Raharjo 2014, 65).

Pasca jatuhnya Orde Baru pada tahun 1998 dan terjadinya Reformasi yang menimbulkan pergolakan di dalam negeri, permasalahan Laut Tiongkok Selatan kurang menjadi fokus bagi pemerintahan selanjutnya hingga Presiden Susilo Bambang Yudhoyono mulai menjabat (Raharjo 2014). Gaya kebijakan luar negeri Indonesia pada era Presiden Susilo Bambang Yudhoyono yang memiliki slogan "Thousand Friends, Zero Enemy" yang berarti Indonesia secara aktif mengutamakan jalan perundingan dan perdamaian tanpa menggunakan senjata dalam setiap pertikaian menjadi acuan 
Muhammad Shuttle Diplomacy Indonesia di ASEAN Terkait Konflik Laut

Naufal Aziz Tiongkok Selatan

bagaimana kebijakan luar negeri Indonesia di rencanakan dan diimplementasikan.

Pada pertemuan AMM ke 45 di Kamboja pada tahun 2012, Negaranegara ASEAN terbelah dalam mendudukkan posisi dan peran Tiongkok. Di satu pihak, sebagian negara ASEAN seperti Kamboja berpendapat bahwa Tiongkok harus dilibatkan sejak awal dalam proses perumusan Code of Conduct. Sebagian anggota lain, khususnya Filipina dan Vietnam, berpendapat bahwa ASEAN harus menyatukan posisi terlebih dulu sebelum menyodorkan draft Code of Conduct untuk dinegosiasikan dengan Tiongkok (Sukma 2012). Kejadian ini membuat ASEAN gagal untuk mengeluarkan joint communique tentang permasalahan LTS untuk pertama kalinya dalam 45 tahun perjalanan ASEAN

Pasca gagalnya pertemuan AMM ke 45 tersebut, Menteri Luar Negeri Indonesia, Marty Natalegawa melakukan mediasi melalui Shuttle Diplomacy ke 4 negara ASEAN, yaitu Filipina, Vietnam, Kamboja dan Singapura selama dua hari pada tanggal 18 - 19 Juli 2012 dan mendorong untuk disepakatinya 6 poin komitmen oleh Menteri Luar Negeri yang ada di ASEAN untuk mematuhi Declaration on the Conduct of Parties in the South China Sea dan mengikuti pedoman pelaksanaannya serta menahan diri dan menghindari ancaman atau penggunaan kekerasan; untuk menegakkan penyelesaian sengketa 
Muhammad Shuttle Diplomacy Indonesia di ASEAN Terkait Konflik Laut

Naufal Aziz Tiongkok Selatan

damai sesuai dengan prinsip-prinsip hukum internasional yang diakui secara universal, termasuk Konvensi Perserikatan Bangsa-Bangsa tentang Hukum Laut (UNCLOS). Draft komunike ini berhasil dengan ditandatanganinya 6 poin komitmen oleh negara-negara ASEAN pada tanggal 20 Juli 2012 dan menggantikan hasil dari pertemuan tingkat menteri yang gagal sebelumnya (Emmerson, 2012).

Untuk sementara waktu, perjanjian ini berhasil menjaga persatuan negara-negara ASEAN terbukti dengan berkurangnya konflik kepentingan yang terjadi diantara negara-negara anggota ASEAN, salah satu indikator keberhasilan ini adalah pada tahun berikutnya (2013) ketika Brunei menjadi chair ASEAN, proses pembuatan joint communique menjadi lebih mudah tanpa adanya tekanan yang berarti dari negara anggota (Sarith 2013) dan melalui shuttle diplomacy yang dilakukan oleh Marty Natalegawa berhasil menjembatani kepentingan ASEAN dan Tiongok di Laut Tiongkok Selatan.

Berdasarkan fenomena tersebut, menarik untuk diketahui apa saja faktor yang menyebabkan shuttle diplomacy bisa berhasil dilakukan dalam waktu hanya 2 hari, mengingat bahwa beberapa hari sebelumnya negara-negara ASEAN mencapai kebuntuan terkait permasalahan Laut Tiongkok Selatan sehingga tidak tercapai sebuah joint communique dalam pertemuan AMM ke 45. 
Muhammad Shuttle Diplomacy Indonesia di ASEAN Terkait Konflik Laut

Naufal Aziz Tiongkok Selatan

\section{Metode Penelitian}

Penelitian ini menggunakan konsep Shuttle Diplomacy oleh David A. Hoffman (Hoffman 2013) untuk menjelaskan misi diplomatik yang dilakukan oleh Marty Natalegawa ke 4 negara ASEAN, kemudian konsep ini akan dielaborasikan dengan konsep mediasi oleh Lawrence Susskind dan Eileen Babbit dalam buku Mediation in International Relations : Multiple Approaches to Conflict Management (Susskind dan Eileen 1992, 31-36) untuk menjabarkan apa saja faktor yang membuat sebuah usaha mediasi bisa berjalan efektif, dimana terdapat 5 prakondisi yang harus dipenuhi yaitu:

1. Pihak yang berkonflik harus memiliki kesadaran bahwa aksi unilateral (sebelah pihak) tidak akan menyelesaikan konflik.

2. Perjanjian yang disusun merupakan alternatif untuk menghindarkan efek konflik yang berkepanjangan baik secara ekonomi, politik maupun psikologi.

3. Delegasi/Perwakilan dari pihak yang bersengketa harus memiliki otoritas/pengaruh yang cukup bagi pihak yang diwakilinya dan memiliki komitmen dalam menerapkan tindakan yang disepakati bersama.

4. Adanya kepentingan internasional dan regional lain di dalam konflik sehingga diperlukan tekanan menuju proses resolusi. 
Muhammad Shuttle Diplomacy Indonesia di ASEAN Terkait Konflik Laut

Naufal Aziz Tiongkok Selatan

5. Pihak yang menjadi mediator (penengah) di dalam perundingan adalah pihak yang bisa diterima oleh segala pihak.

\section{Pembahasan}

Bagian ini membahas faktor-faktor yang mendukung keberhasilan mediasi Indonesia dalam menyatukan pandangan negaranegara ASEAN yang terpecah pasca pertemuan AMM (ASEAN Ministerial Meetings) ke 45 di Kamboja melalui shuttle diplomacy yang dilakukan oleh Menteri Luar Negeri Marty Natalegawa dan juga hasil yang didapatkan pasca pertemuan selama 2 hari tersebut.

\section{Shuttle Diplomacy Indonesia}

Indonesia melalui Menteri Luar Negeri Marty Natalegawa merespon kegagalan negara-negara ASEAN untuk menyatukan pandangannya terkait permasalahan LTS di pertemuan para menteri tingkat ASEAN (AMM) ke 45 dengan melakukan perjalanan dalam 2 hari ke 4 negara ASEAN yaitu Filipina, Vietnam, Kamboja dan Singapura. Perjalanan ini dinamakan sebagai shuttle diplomacy. Jenis diplomasi ini pertama kali dilakukan oleh mantan Menteri Luar Negeri Amerika Serikat Henry Kissinger pasca terjadinya perang yom kippur antara Israel dan negara-negara Arab, Kissinger dan Presiden Amerika Jimmy Carter melakukan misi diplomatik bolak-balik untuk meredam tensi konflik diantara negara yang bertikai ke Israel dan perwakilan negara arab saat itu, Mesir dengan menghasilkan perjanjian Camp 
Muhammad Shuttle Diplomacy Indonesia di ASEAN Terkait Konflik Laut Naufal Aziz Tiongkok Selatan

David, setelah itu penggunaan jenis diplomasi ini menjadi lebih sering sehubungan dengan perkembangan teknologi komunikasi dan transportasi sehingga jenis diplomasi ini menjadi lebih memungkinkan untuk dilakukan.

Terdapat beberapa aktivitas yang menyebabkan usaha mediasi yang dilakukan oleh Marty Natalegawa bisa digolongkan sebagai shuttle diplomacy menurut Heidi Burgess, yaitu:

1. Adanya pihak ketiga (dalam hal ini bisa individu, negara maupun organisasi internasional) yang memposisikan dirinya secara netral dan objektif untuk menyampaikan informasi secara bolak-balik antara para pihak yang bertikai. Indonesia telah menunjukkan posisinya dalam konflik LTS secara umum sebagai pihak ketiga yang tidak memihak, dalam artian bukan termasuk kedalam salah satu kubu yang bertikai. Dalam mengkonsolidasikan suara ASEAN yang terpecah, diantara negara yang berpendapat bahwa dalam penyusunan draft tata cara berperilaku atau COC (code of conduct) di LTS harus melibatkan Tiongkok karena konflik Vietnam, Filipina dan Tiongkok di wilayah Spartly merupakan ranah bilateral dan tidak bisa diselesaikan secara multilateral karena tidak seluruh wilayah LTS yang diikutkan yaitu Kamboja dengan negara-negara yang menginginkankan adanya pembahasan konflik LTS (khususnya tentang kepulauan Scarborough) dalam pertemuan AMM, sehingga negara-negara ASEAN bisa 
Muhammad Shuttle Diplomacy Indonesia di ASEAN Terkait Konflik Laut

Naufal Aziz Tiongkok Selatan

menyamakan pandangannya terlebih dahulu menyangkut wilayah yang menjadi titik utama sengketa tersebut sebelum bertemu dengan Tiongkok (Natalegawa 2013). Indonesia menempatkan diri sebagai pihak penengah dan meyakinkan negara-negara ASEAN (khususnya negara yang berbeda pendapat) bahwa permasalahan ini harus diselesaikan melalui jalan perundingan dan diplomasi dalam kerangka ASEAN sehingga bisa mengurangi eskalasi konflik yang berakibat pada instabilitas keamanan di ASEAN (Natalegawa 2013).

Paham dynamic equilibrium yang dipakai sebagai kebijakan luar negeri Indonesia pada masa Menlu Marty Natalegawa menjabat membutuhkan sebuah kondisi kawasan yang stabil, sehingga prioritas Indonesia dalam konteks konflik LTS adalah untuk mengembalikan strategic trust diantara negara-negara ASEAN dibandingkan kepentingan lainnya, oleh karena itu menjaga netralitas Indonesia dalam konflik LTS menjadi hal yang mutlak harus dilakukan untuk mengembalikan kepercayaan diantara negara-negara ASEAN. Sikap Indonesia juga tergambar dalam siaran pers Kementrian Luar Negeri Indonesia:

Sekali lagi, Indonesia menyerukan kepada kedua pihak untuk menahan diri, menghormati komitmen-komitmen yang tercermin dalam Declaration on the Conduct of the Parties in the South China Sea (DOC) dan menghindari langkah-langkah yang dapat menambah ketegangan dan beresiko menciptakan eskalasi. Indonesia selanjutnya menyerukan kepada kedua pihak untuk berkomunikasi 
Muhammad Shuttle Diplomacy Indonesia di ASEAN Terkait Konflik Laut

Naufal Aziz Tiongkok Selatan

guna menstabilkan situasi, termasuk melalui pemanfaatan jalur komunikasi hotline yang telah disepakati sebelumnya.

2. Pihak ketiga tidak hanya menjadi perantara namun juga bisa mengarahkan konflik kepada proses resolusi dan dilakukan di dalam ruang privat. Sebelum chair ASEAN mengeluarkan pernyataan bersama Six Point Principles on the South China Sea yang mengganti joint communique yang tidak tercapai sebelumnya, Menteri Luar Negeri Indonesia Marty Natalegawa sebagai pihak ketiga di dalam konflik LTS melakukan perjalanan ke 4 negara ASEAN dalam 2 hari dengan membawa usulan proposal Six Point of Principle on The South China Sea, proposal ini merupakan salah satu usaha dalam mengarahkan kepada usaha resolusi konflik dengan mengakomodir keinginan semua pihak dalam sebuah kondisi zero sum game dan bukan hanya sekedar mendengarkan pendapat masing-masing pihak. Proses shuttle diplomacy yang dilakukan oleh Marty Natalegawa dilakukan didalam ranah privat, dalam artian dilakukan secara terpisah terlebih dahulu (menemui pihak terkait di negara masing-masing) sebelum dipertemukan didalam sebuah konferensi sehingga bisa menghindari kebuntuan yang terjadi dimana Filipina dan Vietnam menuduh keputusan Kamboja untuk tidak meloloskan usulan mereka pada AMM 45 disebabkan karena keberpihakan Kamboja kepada Tiongkok dalam permasalahan LTS yang ditanggapi oleh Kamboja dengan menarik duta besarnya dari Manila (Kistyarini 2012). 
Muhammad Shuttle Diplomacy Indonesia di ASEAN Terkait Konflik Laut

Naufal Aziz Tiongkok Selatan

\section{Mediasi Indonesia melalui Shuttle Diplomacy}

Terdapat proses mediasi didalam Shuttle Diplomacy yang dilakukan oleh Marty Natalegawa karena adanya faktor pihak ketiga yang mendamaikan, sehingga usaha yang dilakukan juga perlu dijelaskan di dalam kerangka mediasi. Menurut Lawrence Susskin dan Eileen Babbit dalam buku Mediation in International Relations: Multiple Aproaches to Conflict Management (Susskind dan Eileen 1992, 31-36) terdapat 5 prakondisi yang harus dipenuhi sehingga membuat sebuah usaha mediasi bisa berjalan dengan efektif. Kelima prakondisi ini akan dijabarkan beserta studi kasus untuk menjelaskan keberhasilan mediasi dalam shuttle diplomacy yang dilakukan selama 2 hari oleh Marty Natalegawa.

\section{Kesadaran Aksi Unilateral Tidak Akan Menyelesaikan Konflik}

Untuk mencapai hasil akhir terbaik berupa tercapainya konsensus diantara negara-negara ASEAN yang berbeda pendapat di pertemuan AMM ke 45, Indonesia sebagai mediator harus memastikan terlebih dahulu adanya kesadaran (awarness) bahwa aksi unilateral (bertindak sendiri) tidak akan menyelesaikan konflik, bahkan akan memperburuk keadaan. Perjalanan pertama dilakukan oleh Menteri Luar Negeri Marty Natalegawa pada tanggal 18 Juli 2012 ke Filipina, salah satu aktor utama dari konflik LTS secara umum karena memiliki kepentingan klaim di wilayah Kepulauan Scarborough (BBC 2012) juga 
Muhammad Shuttle Diplomacy Indonesia di ASEAN Terkait Konflik Laut

Naufal Aziz Tiongkok Selatan

menolak keras kehadiran Tiongkok di dalam perundingan-perundingan ASEAN seperti yang diusulkan oleh Kamboja dalam pertemuan AMM ke 45. Kesadaran untuk menyelesaikan permasalahan, khususnya yang melibatkan Filipina di wilayah yang disengketakan (kepulauan Scarborough) dalam kerangka ASEAN setidaknya bisa dilihat di dalam statement Wakil Menteri Luar Negeri Filipina, Erlinda F. Basilio:

The Philippines has been in continuous consultations with its ASEAN partners resulting in the ASEAN Senior Officials drafting of an "ASEAN Foreign Ministers' Statement on the Situation in Scarborough Shoal" on 24 May. On 25 May, Secretary del Rosario wrote the ASEAN Chair requesting that such Statement be referred to all ASEAN Foreign Ministers for their consideration. (Basilio)

Kemudian, Menteri Luar Negeri Del Rosario dan beberapa Menteri Luar Negeri ASEAN juga sudah berusaha untuk melakukan revisi pada beberapa point komunike terkait Kepulauan Scarborough agar bisa diterima oleh semua pihak sebagai win-win solution pada pertemuan tingkat menteri ASEAN ke 45 ini (Basilio). Walaupun usaha ini menemui kebuntuan, bisa disimpulkan bahwa Filipina telah berusaha untuk menyelaraskan kepentingannya di Kepulauan Scarborough dengan cara dan norma yang berlaku di ASEAN sebelum menempuh cara-cara legal lainnya. Hal ini kemudian yang membuat Filipina melalui Menteri Luar Negeri Del Rosario menyambut dengan baik usulan draft Six Point of Principles on the South China Sea yang coba diajukan oleh Menteri Luar Negeri Marty Natalegawa. Sikap yang ditunjukan oleh Vietnam melalui Menteri Luar Negeri Pham Binh Ming juga tidak jauh beda dengan Filipina mengingat dua negara inilah yang 
Muhammad Shuttle Diplomacy Indonesia di ASEAN Terkait Konflik Laut

Naufal Aziz Tiongkok Selatan

memiliki inisiatif untuk memasukkan pembahasan tentang kepulauan Scarborough di dalam pertemuan AMM. Hal ini berarti Vietnam juga mendukung untuk penyelesaian konflik melalui cara multilateral/melalui ASEAN bukan melalui cara bilateral seperti yang dikehendaki oleh Tiongkok.

Keinginan untuk menyelesaikan konflik LTS secara multilateral (melalui ASEAN) telah ditunjukkan oleh Vietnam sejak pertemuan ASEAN (ASEAN Summit) ke 17 di Jakarta, dimana saat itu Vietnam mendesak untuk mengganti kalimat "the South China Sea issue was best handled either bilaterally or among the states concerned" pada draft pernyataan final dengan kalimat "the need to further intensify the efforts of both ASEAN and China.". Sekretariat ASEAN menyetujui kalimat ini dan menggantinya beberapa hari setelah pertemuan (Shoji 2012, 8). Setelah memastikan sikap kedua negara tersebut, kemudian pekerjaan yang cukup sulit berikutnya adalah memastikan awarness dari negara Kamboja, mengingat posisi Kamboja sebagai chair ASEAN saat itu sedikit lebih memiliki pengaruh daripada posisi Indonesia secara umum dalam konteks pertemuan ASEAN dan mendapat pengaruh maupun tekanan dari Tiongkok dalam melaksanakan tugasnya di ASEAN. Namun fakta bahwa pada tahun sebelumnya (2011) ketika chair ASEAN diduduki oleh Indonesia, Menteri Luar Negeri Marty berhasil mendamaikan Kamboja dan Thailand dalam konflik perbatasan di Preah Vihear membuat Kamboja lebih bersikap terbuka terhadap 
Muhammad Shuttle Diplomacy Indonesia di ASEAN Terkait Konflik Laut Naufal Aziz Tiongkok Selatan

inisiatif yang coba dilakukan oleh Marty Natalegawa, terbukti dari pernyataan Perdana Menteri Kamboja, Kim Hourn “We're looking forward to welcoming Marty in Cambodia. We, of course, appreciate his role. When Indonesia was (ASEAN) chair last year, he was quite constructive.” (Seiff, 2012).

Sementara perjalanan 2 hari Menteri Luar Negeri Marty Natalegawa berakhir di Singapura untuk memastikan sikap Singapura mendukung langkah diplomasi yang diambil oleh Indonesia pasca pertemuan AMM ke 45, mengingat status Singapura yang sama dengan Indonesia bukan termasuk sebagai negara pengklaim namun memiliki kepentingan akan kebebasan jalur perdagangan di wilayah LTS. Dukungan Singapura terhadap Indonesia penting karena Singapura termasuk salah satu mitra dagang penting bagi Tiongkok di ASEAN sekaligus sebagai mitra terdekat bagi Amerika Serikat di wilayah Asia Tenggara. Indonesia perlu untuk memperkuat basis diplomasinya ke Kamboja yang menolak untuk "meng-internasionalisasikan" kasus LTS, dengan meyakinkan Singapura untuk tidak membawa Amerika Serikat ikut campur di masalah LTS berarti juga mengurangi beban diplomasi Marty Natalegawa ke Kamboja. (Jenner 2017, 92). Kesadaran Singapura terhadap isu LTS tercermin di dalam pernyataan Perdana Menteri Singapura, Lee Hsien Loong dengan mendorong ASEAN “Has to take and state a position which is neutral, forward-looking and encourages the peaceful resolution of issues." (Perlez, 2012). 
Muhammad Shuttle Diplomacy Indonesia di ASEAN Terkait Konflik Laut Naufal Aziz Tiongkok Selatan

Indonesia, sebagai natural leader ASEAN ikut berperan dalam membangun kesadaran akan perlunya penyelesaian konflik yang terjadi di wilayah Asia Tenggara (khususnya wilayah LTS) secara damai dan sesuai dengan ASEAN Way dalam kerangka organisasi regional ini dengan diinisiasinya workshop bersifat non-formal, Managing Potential Conflicts in the South China Sea pada tahun 1988. Workshop telah ini berhasil meningkatkan kepercayaan dan mengurangi kecurigaan yang terjadi diantara negara yang berkonflik, mendorong adanya pertukaran informasi dan pandangan serta mengadakan kerjasama dalam pemanfaatan potensi alam di LTS untuk pertamakalinya (Wahyudi). Workshop ini merupakan salah satu cara untuk melakukan de-eskalasi konflik yang efektif selama 10 tahun sebelum terciptanya DOC, karena telah menjadi wadah untuk meredakan ketegangan yang berlangsung sebelum menuju tahap pencarian solusi konflik LTS secara kolektif di antara negara-negara ASEAN (Wahyudi).

Kesadaran negara-negara anggota ASEAN bahwa aksi unilateral bukanlah langkah yang menguntungkan sebenarnya sudah terbentuk sejak lama, dan Indonesia merupakan salah satu aktor penting yang membentuk kesadaran tersebut selain beberapa faktor lainnya seperti perbedaan yang cukup signifikan dalam konteks power masing-masing negara (Rata-rata negara anggota ASEAN tergolong negara smallmiddle power sehingga tidak mungkin menghadapi Tiongkok yang 
Muhammad Shuttle Diplomacy Indonesia di ASEAN Terkait Konflik Laut

Naufal Aziz Tiongkok Selatan

merupakan raising big power sendirian), sehingga tugas Marty Natalegawa dalam shuttle diplomacy yang dilakukannya tersebut cukup hanya dengan memanggil kembali kesadaran tersebut.

\section{Perjanjian Yang Disusun Merupakan Sebuah Alternatif Untuk Menghindarkan Konflik Yang Berkepanjangan}

Tidak tercapainya konsensus ASEAN dalam pembahasan konflik LTS (khususnya joint communique tentang konflik di wilayah kepulauan Scarborough) yang diusulkan oleh Vietnam dan Filipina di pertemuan AMM ke 45 di Kamboja merupakan kejadian yang pertama kali terjadi di dalam pertemuan-pertemuan ASEAN sejak organisasi ini pertama kali berdiri. Hal ini merupakan sebuah indikasi adanya perpecahan diantara negara-negara ASEAN karena setiap negara mulai bertindak jauh dari "ASEAN Way" atau penyelesaian masalah melalui dialog, konsensus, musyawarah dan mufakat dan akan berdampak pada sentralitas ASEAN itu sendiri. Lebih lanjut, perbedaan pendapat yang terjadi diantara negara ASEAN diambang negosiasinya dengan Tiongkok membuat situasi ini akan lebih buruk. Seperti yang sudah dipaparkan sebelumnya, penyelesaian konflik secara bilateral merupakan keinginan Tiongkok, faktor tidak adanya negara ASEAN yang dapat mengimbangi power Tiongkok merupakan sebuah kemenangan awal bagi Tiongkok dalam perundinganperundingan terkait Laut Tiongkok Selatan. Juga, hal ini akan 
Muhammad Shuttle Diplomacy Indonesia di ASEAN Terkait Konflik Laut

Naufal Aziz Tiongkok Selatan

mengurangi kemampuan ASEAN sebagai aktor kolektif untuk berunding dengan negara besar lainnya.

Dampak lainnya adalah pembicaran COC yang digagas akan semakin jauh dari kenyataan sehingga dapat memicu perang terbuka karena tidak adanya aturan baku yang harus dipatuhi bersama di wilayah konflik. Beberapa hal inilah yang kemudian menjadi alasan kenapa negara anggota ASEAN harus kembali satu suara dalam menghadapi konflik setidaknya untuk mengembalikan kepercayaan diantara negara anggota terlebih dahulu. Six Point of Principles on The South China Sea yang diajukan oleh Marty Natalegawa menawarkan sebuah alternatif bagi kondisi ini, karena Marty Natalegawa mencoba untuk mengakomodir semua pihak yang ada sembari tetap sesuai dengan norma-norma yang berlaku di Asia Tenggara. Hal ini bisa dilihat dari draft usulan Menteri Luar Negeri Marty Natalegawa yang meminta kembali komitmen negara-negara ASEAN dalam beberapa point, yaitu:

1. Implementasi penuh DOC yang disepakati ASEAN pada tahun 2002

2. Komitmen untuk mematuhi guidelines atau panduan pengimplementasian DOC pada tahun 2011

3. Penetapan kesimpulan awal COC (tata cara perilaku di LTS) 
Muhammad Shuttle Diplomacy Indonesia di ASEAN Terkait Konflik Laut Naufal Aziz Tiongkok Selatan

4. Penyelesaian konflik yang sesuai dengan Hukum Internasional yang berlaku termasuk Hukum Laut UNCLOS

5. Mempertahankan perilaku untuk menahan diri (untuk tidak memulai konflik baru) dan tidak menggunakan kekerasan oleh semua pihak

6. Mencari penyelesaian konflik yang damai dan sesuai dengan hukum Internasional yang berlaku

Didalam draft yang diajukan juga terdapat dorongan untuk mengintesifkan konsultasi lanjutan diantara Menteri Luar Negeri ASEAN sesuai dengan cara-cara ASEAN yaitu, cara penyelesaian konflik yang damai sesuai dengan TAC dan Piagam ASEAN 2008. Ratifikasi draft alternatif ini juga merupakan sebuah warning kepada Kamboja untuk tidak memanfaatkan posisinya sebagai chair ASEAN demi mengejar kepentingan tertentu yang akan mengorbankan posisi negara anggota ASEAN lainnya (Thayer 2012). Sehingga bisa disimpulkan draft ini diajukan untuk menyelamatkan "wajah” ASEAN dan untuk mengembalikan kepercayan negara-negara anggota terhadap organisasi regional satu-satunya di kawasan ini.

Perwakilan Dari Pihak Yang Bersengketa Memiliki Otoritas Untuk Mewakili Pihaknya Sendiri dan Memiliki Komitmen UntukMenerapkan Tindakan Yang Disepakati

Dalam kunjungannya ke 4 Negara, Marty Natalegawa diterima langsung oleh Menteri Luar Negeri masing-masing negara, yaitu 
Muhammad Shuttle Diplomacy Indonesia di ASEAN Terkait Konflik Laut Naufal Aziz Tiongkok Selatan

Sekretaris Urusan Luar Negeri (Secretary of Foreign Affairs) Filipina Albert del Rosario dalam kunjungannya di Manila pada tanggal 18 Juli 2012. Kemudian dengan Menteri Luar Negeri Vietnam Pham Binh Ming di Hanoi. Perjalanan di hari berikutnya ke Phnom Penh, Marty Natalegawa bertemu dengan Menteri Luar Negeri Hor Namhong dan yang terakhir adalah bertemu dengan Menteri Urusan Luar Negeri dan Hukum Singapura, Kasiviswanathan Shanmugam. Hal ini bisa disimpulkan bahwa pihak-pihak yang bersengketa telah diwakili oleh perwakilan yang "representatif" mengingat jabatan Menteri Luar Negeri merupakan otoritas tertinggi dibawah presiden yang menangani permasalahan Luar Negeri. Penandatangan atau ratifikasi draft alternatif Six Point of Principles on The South China Sea yang diajukan oleh Marty Natalegawa untuk menggantikan draft komunike yang tidak bisa disepakati sebelumnya merupakan bentuk komitmen masing-masing negara terhadap penyelesaian masalah.

\section{Adanya Kepentingan Internasional atau Regional Lain di Dalam Konflik Sehingga Diperlukan Tekanan Menuju Proses Resolusi}

Kegagalan negara-negara ASEAN dalam menentukan sikap bersama terhadap permasalahan di Laut Tiongkok Selatan telah menimbulkan kekhawatiran di dunia internasional, mengingat wilayah perairan ini merupakan salah satu jalur utama perdagangan dunia yang menghubungkan samudera hindia dan samudera pasifik. Salah satu negara yang menunjukkan perhatiannya adalah Jepang, pada sesi 
Muhammad Shuttle Diplomacy Indonesia di ASEAN Terkait Konflik Laut Naufal Aziz Tiongkok Selatan

ASEAN + 3 di pertemuan ke 21 ASEAN dan negara Asia Timur, seperti yang disampaikan Perdana Menteri Yoshiko Noda "raised the issue of the South China Sea, noting that this is of common concern for the international community, which would have direct impact on peace and stability of the Asia-Pacific.” (Szep 2012). Kekhawatiran Jepang ini beralasan karena hampir 60\% (3,4 Tcf) pasokan energi Jepang dari negara teluk melewati wilayah ini. Kestabilan dan keamanan wilayah yang dilalui menjadi sebuah isu yang serius dengannya kemudian.

Amerika Serikat juga merupakan negara yang menunjukkan perhatian besar terhadap permasalahan LTS, Karena Amerika Serikat sebagai negara yang kuat secara ekonomi (AS menyumbang 26\% GDP Dunia) dan sebagai negara investor terbesar di dunia (sebesar 3,259 triliun dollar pada tahun 2010) sangat bergantung pada perdagangan global untuk penyaluran barang ekspornya sehinga perlu bagi Amerika Serikat untuk memperhatikan stabilitas di wilayah-wilayah mitra perdagangannya, termasuk di Asia Tenggara (Widhawaty 2016). Intimidasi Tiongkok pada perusahaan minyak asal Amerika Serikat di Vietnam seperti ExxonMobil di wilayah perairan Vietnam dan kepentingan untuk memastikan akses tanpa hambatan (dalam hal ini, wilayah laut dan udara internasional yang ikut diklaim oleh Tiongkok) pada global commons juga menjadi alasan kenapa Amerika Serikat menjadikan konflik LTS menjadi fokus kebijakan luar negerinya pada masa pemerintahan Barrack Obama (Widhawaty 2016). 
Muhammad Shuttle Diplomacy Indonesia di ASEAN Terkait Konflik Laut Naufal Aziz Tiongkok Selatan

Keterlibatan langsung Amerika Serikat di konflik LTS menjadi memungkinkan karena Filipina memiliki perjanjian Mutual Defense Treaty dengan Amerika Serikat sejak tahun 1951 yang berisi "Each Party recognizes that an armed attack in the Pacific Area on either of the Parties would be dangerous to its own peace and safety and declares that it would act to meet the common dangers in accordance with its constitutional processes.” (Gleser 2012, 7). Hal ini berarti Amerika bisa menerjunkan pasukannya jika Filipina mulai merasa terancam. Keikutsertaan Amerika Serikat di dalam konflik LTS dinilai akan menjadikan keadaan lebih buruk dan menyebabkan kemungkinan terjadinya perang terbuka lebih tinggi. Sejauh ini Amerika Serikat masih menempatkan diri sebagai kekuatan penyeimbang (tidak terlibat langsung), dimana secara berkala sejak tahun 2010 Amerika Serikat meningkatkan kerjasama militer dengan Filipina dan Vietnam, Memberikan bantuan asistensi keamanan dan melanjutkan penjualan senjata ke negara-negara dagang utama di Asia Tenggara (Darmawan dan Gebyar 2017, 14).

Uni Eropa merupakan salah satu organisasi regional lain yang menunjukkan perhatiannya pada konflik LTS. Hal ini ditunjukkan dengan kehadiran perwakilan urusan kebijakan luar negeri dan keamanan UE Catherine Ashton dalam ASEAN Regional Forum sekaligus ikut menandatangani TAC yang ada di Asia Tenggara. UE juga mengularkan joint statement dengan Amerika Serikat yang 
Muhammad Shuttle Diplomacy Indonesia di ASEAN Terkait Konflik Laut

Naufal Aziz Tiongkok Selatan

mendesak Tiongkok dan ASEAN untuk menetapkan sebuah Code of Conduct yang lebih mengikat sehingga bisa menjamin jalur perdagangan dunia yang dimana Uni Eropa juga bergantung didalamnya (Sudira, 149).

Kegagalan AMM ke 45 telah menyebabkan ketegangan baru dalam konflik LTS, sehingga diperlukan sebuah langkah preventive untuk meredakan kondisi di wilayah konflik dan menyatukan kembali suara ASEAN diantara ancaman Tiongkok dan kehadiran Amerika Serikat. Jepang yang juga tergabung kedalam ASEAN+3 juga memiliki kepentingan untuk melindungi jalur energinya di wilayah Laut Tiongkok Selatan dan memilih untuk memperjuangkan kepentingannya melalui organisasi regional yang berada di wilayah konflik untuk menghindari eskalasi konflik lebih lanjut,hal yang sama juga dilakukan oleh Uni Eropa. Hal inilah yang menyebabkan usaha mediasi yang dilakukan oleh Marty Natalegawa menjadi langkah yang tepat.

Pihak yang Menjadi Mediator Adalah Pihak yang Bisa Diterima Oleh Semua Pihak

Menurut Jacob Bercovitch dan Jeffrey Z.Rubin, Mediator adalah pihak yang tidak terlibat langsung (netral) dalam sebuah krisis, bertujuan untuk mengubah atau mempengaruhi persepsi dan perilaku pihak-pihak yang berkonflik tanpa menggunakan tekanan fisik secara 
Muhammad Shuttle Diplomacy Indonesia di ASEAN Terkait Konflik Laut

Naufal Aziz Tiongkok Selatan

langsung maupun dengan menempuh jalur-jalur hukum tertentu (Bercovitch dan Jeffrey 1992, 3). Jacob mengelompokkan mediator berdasar jenis aktor yang ada di dunia internasional yaitu Individu maupun Professional, Negara, dan Organisasi/ institusi. Dalam hal ini, Marty Natalegawa digolongkan sebagai mediator negara karena bagian dari decision makers Indonesia dalam urusan Luar Negeri sehingga bisa dianggap sebagai representatif dari Indonesia. Berdasarkan motifnya, aktor negara yang menjadi mediator di dalam konflik dapat dibagi atas beberapa tipe:

1. Mendapat mandat secara resmi dari organisasi internasional tertentu untuk menangani konflik.

2. Memiliki keinginan untuk mengubah jalannya konflik, karena keberlangsungan konflik diprediksi akan mempengaruhi kepentingan dari pihak mediator di kemudian hari.

3. Diminta oleh salah satu atau kedua pihak yang berkonflik untuk ikut serta menyelesaikan permasalahan.

4. Memiliki keinginan untuk menyelesaikan konflik dalam rangka mempertahankan sebuah struktur yang dimana pihak mediator adalah bagian dari struktur tersebut.

5. Melihat mediasi sebagai peluang untuk memperluas dan meningkatkan pengaruh sekaligus untuk meraih kepercayaan politik dari pihak yang berkonflik. 
Muhammad Shuttle Diplomacy Indonesia di ASEAN Terkait Konflik Laut Naufal Aziz Tiongkok Selatan

Secara umum, motif Indonesia di dalam mediasi konflik LTS dapat digolongkan ke point 2, 4 dan 5 karena garis klaim Tiongkok di LTS menyinggung wilayah laut natuna yang memiliki cadangan minyak dan gas yang cukup besar, sehingga jika dibiarkan akan berdampak pada kepentingan nasional Indonesia nantinya, lalu point 4 dan 5 diperkuat dengan statement Marty Natalegawa:

In recent years, Indonesia has been at the forefront in ensuring that the group's much-cited principle of being in the 'driving seat' of regional integration is tangibly realised in the association's engagement with its external partners. In this way Indonesia has, again in a judicious and consensusbuilding manner, sought to provide leadership in ASEAN.....Indonesia's leadership on regional security has clearly extended beyond regional architecture-building. A case in point was its role in managing the real potential for conflict between Cambodia and Thailand in 2011 over the disputed Preah Vihear temple in the border region. Another was its unprecedented 'shuttle diplomacy' in 2012 that helped restore ASEAN unity on the issue of the South China Sea through the adoption of the so-called 'Six Point Principles'. (Natalegawa 2015)

Lebih lanjut, peran Indonesia sebagai mediator, fasilitator dan pengamat konflik di ASEAN bukanlah sebuah hal yang baru, sejak era perang dingin, Indonesia sudah menunjukkan peran aktifnya dalam proses pendamaian konflik internal Kamboja melalui the Jakarta Informal Meeting I and I. (Alexandria 2015, 6). Indonesia juga terlibat 
Muhammad Shuttle Diplomacy Indonesia di ASEAN Terkait Konflik Laut Naufal Aziz Tiongkok Selatan

dalam mewujudkan perdamaian antara pemerintahan Filipina dengan Moro National Liberation Front (MNLF) sejak tahun 1993, lalu Indonesia juga menjadi fasilitator dalam permasalahan antara Pemerintahan Thailand dengan Kelompok Muslim di Thailand Selatan lalu Indonesia juga memainkan peran penting dalam proses demokratisasi di Myanmar. Pengalaman-pengalaman yang di dapat oleh Indonesia dari setiap konflik yang ada di ASEAN ini mengukuhkan arti penting Indonesia di kawasan selain faktor-faktor lain yang dimiliki oleh Indonesia, sehingga penerimaan negara-negara ASEAN terhadap mediasi yang dilakukan oleh Marty Natalegawa menjadi masuk akal.

Secara spesifik, posisi Indonesia dalam konflik LTS yang bukan termasuk negara pengklaim telah memudahkan usaha mediasi yang coba dilakukan oleh Marty Natalegawa. Dalam setiap pertemuan yang membahas permasalahan LTS, Indonesia dianggap sebagai pihak yang netral (pihak ketiga, bukan termasuk negara yang bersengketa) sehingga Indonesia bisa memainkan perannya sebagai perantara yang tidak memihak (Connely, 4). Terlebih pada tahun sebelumnya ketika Indonesia dibawah Marty Natalegawa menjadi chair ASEAN berhasil mendamaikan konflik perbatasan antara Thailand dan Kamboja.

Mely Cabalerro Anthony dari Sekretariat ASEAN menyatakan bahwa keberhasilan Indonesia pada konflik perbatasan ini menjadi sebuah "preseden model mediasi konflik yang efektif dan bentuk constructive 
Muhammad Shuttle Diplomacy Indonesia di ASEAN Terkait Konflik Laut Naufal Aziz Tiongkok Selatan

engagement ala ASEAN yang dimulai secara kekeluargaan dan tidak resmi walaupun secara substansi materinya berbobot." (Priatna 2011) artinya, model penyelesaian konflik dengan cara shuttle diplomacy yang dilakukan oleh Indonesia dalam konflik perbatasan Kamboja - Thailand diakui oleh ASEAN dapat diterapkan utuk konflik-konflik yang terjadi selanjutnya di kawasan. Kamboja yang sebelumnya memperlihatkan sikap penolakan yang kuat terhadap usulan-usulan yang coba diajukan oleh Filipina dan Vietnam menjadi sedikit lebih 'melunak' karena faktor adanya Indonesia didalamnya. Selain itu, waktu yang dibutuhkan untuk membuat kesepakatan baru selama 2 hari untuk menggantikan draft communique yang gagal sebelumnya telah memperlihatkan bahwa Indonesia merupakan pihak yang paling yang bisa diterima oleh semua pihak sehingga bisa berjalan lancar tanpa halangan yang berarti.

Laut Tiongkok Selatan merupakan laut berjenis semi tertutup yang memiliki posisi cukup strategis dalam jalur perlayaran internasional yaitu sebagai penghubung jalur laut (Bottle Neck) antara Samudera Hindia - Samudera Pasifik sehingga menjadikan Laut Tiongkok Selatan sebagai jalur lalu lintas laut tersibuk di dunia. Tercatat lebih dari setengah perdagangan LNG global, sekitar 24\% dari pasokan energi negara-negara Asia Timur dan sepertiga dari total perdagangan global melewati wilayah ini. Laut Tiongkok Selatan juga 
Muhammad Shuttle Diplomacy Indonesia di ASEAN Terkait Konflik Laut Naufal Aziz Tiongkok Selatan

memiliki cadangan SDA gas alam dan minyak yang besar. Potensi sumberdaya yang besar tersebut diiringi dengan potensi konflik yang cukup besar pula.

Tiongkok menjadi aktor utama yang memicu konflik di wilayah ini dengan mengeluarkan klaim bersifat provokatif, the 9 dash line yang jauh melebihi batas-batas wilayah laut sebuah negara yang telah disepakati oleh dunia internasional dalam perjanjian hukum laut UNCLOS pada tahun 1982. Negara-negara yang berada disekitar wilayah LTS (Brunei, Malaysia, Filipina, Vietnam dan Taiwan) segera mengajukan klaimnya masing-masing di beberapa wilayah dengan konsentrasi disekitar kepulauan Spratly, Paratas, Paracel, Macclesfield dan Scarborough. Intensitas konflik semakin meningkat seiring dengan meningkatnya aktivitas di wilayah LTS seperti, eksplorasi gas alam dan minyak, perluasan wilayah penangkapan ikan bahkan sampai pada pembangunan instalasi militer oleh Tiongok di wilayah Spartly.

ASEAN sebagai organisasi regional yang berada diwilayah konflik telah mengusahakan agar konflik bisa diredakan dan diselesaikan dengan prinsip dan norma yang berlaku atau biasa yang disebut dengan ASEAN Way. Prinsip ini mengutamakan cara-cara damai melalui cara perundingan, musyawarah, maupun konsensus. Penyelesaian konflik melalui jalur bilateral dengan Tiongkok dipandang hanya akan merugikan negara-negara Asia Tenggara 
Muhammad Shuttle Diplomacy Indonesia di ASEAN Terkait Konflik Laut Naufal Aziz Tiongkok Selatan

karena tidak berimbangnya kekuatan antar negara tersebut, sehingga menyelesaikan melalui jalur multilateral menjadi jalan yang pas, namun usaha-usaha tersebut masih belum mencapai titik terang, karena belum adanya perjanjian yang mengikat tentang tata-cara berperilaku di wilayah konflik. Usaha de-eskalasi ini semakin diperumit dengan terjadinya perbedaan pendapat negara-negara ASEAN dalam menentukan sikapnya terhadap konflik LTS sehingga untuk pertama kalinya sebuah pertemuan ASEAN gagal menghasilkan draft communique yang diperlukan untuk mengurai permasalahan LTS pada pertemuan AMM ke 45 di Kamboja pada tahun 2012.

Indonesia sebagai natural leader ASEAN yang selama ini telah secara aktif terlibat dalam setiap perundingan-perundingan damai di konflik Laut Tiongkok Selatan kemudian melakukan usaha mediasi dalam bentuk shuttle diplomacy, dimana Menteri Luar Negeri Indonesia Marty Natalegawa melakukan perjalanan selama 2 hari ke 4 negara ASEAN yaitu Filipina, Vietnam, Kamboja dan Singapura. Peneliti menemukan bahwa motif utama Indonesia pada era pemerintahan Susilo Bambang Yudhoyono melakukan ini adalah karena alasan keberlangsungan konflik LTS diprediksi akan mempengaruhi kepentingan dari Indonesia di kemudian hari, karena klaim yang dibuat oleh Tiongkok menyinggung garis batas terluar Indonesia di Natuna yang kaya dengan sumber daya gas alam dan cadangan minyak. 
Muhammad Shuttle Diplomacy Indonesia di ASEAN Terkait Konflik Laut

Naufal Aziz Tiongkok Selatan

Selanjutnya, Indonesia perlu untuk mempertahankan keberlangsungan ASEAN karena selama ini ASEAN merupakan fokus utama kebijakan luar negeri Indonesia dan sehubungan dengan rencana implementasi Masyarakat Ekonomi ASEAN 2015. Lalu yang terakhir Indonesia melihat mediasi yang dilakukan sebagai peluang untuk memperluas dan meningkatkan pengaruh sekaligus untuk meraih kepercayaan politik dari pihak yang berkonflik. Mediasi yang dilakukan oleh Marty Natalegawa dinilai berhasil dengan disetujuinya six point principles on the south china sea 2 hari setelahnya oleh negaranegara yang sebelumnya berbeda pendapat. Mediasi yang dilakukan oleh Marty Natalegawa bisa berhasil dengan waktu cepat karena telah memenuhi 5 prakondisi yang membuat sebuah mediasi bisa berjalan efektif menurut Lawrence Susskind dan Eileen Babbitt yaitu Marty Natalegawa memastikan kesadaran dari negara-negara ASEAN yang terlibat konflik bahwa aksi unilateral (sebelah pihak) tidak akan menyelesaikan konflik. Kemudian perjanjian six point principle on the South China Sea yang disusun merupakan alternatif untuk menghindarkan efek konflik yang berkepanjangan baik secara ekonomi, politik maupun psikologi.

Langkah selanjutnya Marty Natalegawa menemui menteri urusan Luar Negeri masing-masing negara, sebagai pihak yang memiliki otoritas untuk menentukan kebijakan luar negerinya sehingga perjanjian alternatif yang diusulkan bisa diimplementasikan secara 
Muhammad Shuttle Diplomacy Indonesia di ASEAN Terkait Konflik Laut

Naufal Aziz Tiongkok Selatan

efektif. Selain itu adanya kepentingan dari pihak luar seperti dari Amerika Serikat dan Jepang serta dari Uni Eropa untuk memastikan keamanan jalur perdagangan laut internasional memberikan cukup tekanan untuk segera menyelesaikan konflik melalui cara-cara damai dan perundingan. Yang terakhir adalah faktor dari Indonesia itu sendiri, Indonesia yang bukan merupakan negara pengklaim dan dengan track recordnya dalam penanganan konflik di kawasan telah memudahkan usaha mediasi itu sendiri karena Indonesia bisa memposisikan dirinya sebagai honest broker atau pihak ketiga yang netral sehingga bisa lebih diterima oleh negara-negara yang berkonflik.

\section{Kesimpulan}

Pasca pengumuman kesepakatan Six Point Principle on the South China Sea oleh Hor Nam Hong selaku chair ASEAN telah menyelamatkan wajah ASEAN dari bahaya perpecahan di dalam organisasi itu sendiri untuk sementara waktu dan mengembalikan pengaruh organisasi bagi negara anggotanya. Dihadapan ASEAN yang sudah kembali mencapai satu suara, Tiongkok kemudian merespon kesepakatan ini dengan memerintahkan Menteri Luar Negerinya, Yang Jiechi untuk mengunjungi Indonesia dan Malaysia. Dalam konferensi persnya, Menteri Yang menyebutkan bahwa Tiongkok bersedia untuk memperbaiki kerjasama negaranya dengan ASEAN untuk mengimplementasikan DOC dan memulai proses penyusunan COC atas 
Muhammad Shuttle Diplomacy Indonesia di ASEAN Terkait Konflik Laut

Naufal Aziz Tiongkok Selatan

dasar konsensus yang disepakati. Hal ini bisa terjadi sehubungan dengan status Indonesia yang merupakan anggota G-20, dengan begitu telah menaikkan posisi tawar Indonesia terhadap Tiongkok secara khusus, sehingga Tiongkok tidak bisa mengacuhkan usaha diplomasi yang dicoba lakukan oleh Indonesia.

\section{Daftar Pustaka}

Alexandra, Lina. 2015. The Role of Indonesia and ASEAN in Peacebuilding, Policy Brief Series, Centre For Strategic and International Studies.

Anwar, Dewi Fortuna. 1994. "Indonesia's Foreign Policy After the Cold War". Southeast Asian Affairs

Aplianta, Derry. 2015. "Indonesia's Response in the South China Sea Disputes: A comparative analysis of the Soeharto and the postSoeharto era". Journal of ASEAN studies 3:1.

Ba, Alice. 2014. "Perspectives on the South China Sea: Diplomatic, Legal, and Security Dimensions of the Dispute", Central for Strategic and International Studies

Basilio, Erlinda F. "Why There Was No ASEAN Joint Communique". Dokumen Kedutaan Besar Filipina untuk Amerika Serikat

Bercovitch, Jacob dan Jeffrey Z. Rubin. 1992. Mediation in International Relations: Multiple Aproaches to Conflict Management, Palgrave MacMillan.

Berita online BBC. 2012. ASEAN nations fail to reach agreement on South China Sea, diakses13 Juli 2012

Bower, Ernest. "China Reveals Its Hand on ASEAN in Phnom Penh". Center for Strategic and International Studies Journal.

Brown, Harrison dan J. William Fulbright. 1982. China Among the Nations of The Pacific. West View Press.

Burgess, Heidi dan Guy Burgess. 2017. Shuttle Diplomacy/Mediated Communication, 
Muhammad Shuttle Diplomacy Indonesia di ASEAN Terkait Konflik Laut

Naufal Aziz Tiongkok Selatan

http://www.colorado.edu/conflict/peace/treatment/shuttle.htm diakses pada 14 Juni 2017

Buszynski, Leszek, The Development of the South China Sea Maritime Dispute.

Connelly, Aaron L., Indonesia di Laut China Selatan: Berjalan Sendiri, Lowy Institute for International Policy, April 2017

Darmawan, Arief Bakhtiar dan Gebyar Lintang Ndadari. 2017. "Keterlibatan Amerika Serikat dala Sengketa Laut Tiongkok Selatan pada Masa Pemerintahan Presiden Barack Obama". Jurnal Hubungan Internasional 6. (April-September ):1.

Data Luas Wilayah Total Negara-Negara ASEAN. 2016. ASEAN Member States: Selected Basic Indicators. ASEANstats.

Welle, Deutsche. 2017. Cina Protes, TNI AL Tetap Tindak Tegas Pelanggar Kedaulatan, 20 Juni 2016. http://www.dw.com/id/cinaprotes-tni-al-tetap-tindak-tegas-pelanggar-kedaulatan/a19342061 diakses pada 1 Maret 2017

Welle, Deutsche. 2012. Kamboja Tarik Dubes dari Filipina

Djafar, Zainuddin dan Robby Aulia Fadila. 2013. Menuju Peran Strategis Indonesia di Lingkungan Regional dan Global: Politik Luar Negeri Indonesia di Bawah Pemerintahan Susilo Bambang Yudhoyono. Pustaka Jaya.

Dokumen ASEAN. 2002. 2002 Declaration on the Conduct of Parties in the South China Sea. Phnom

Dokumen ASEAN. 2011. Guidelines for the Implementation of the DOC.

Dokumen ASEAN, Joint Communique of The 29th ASEAN Ministerial Meeting, Jakarta, Juli 1996

Dokumen Joint Statement of The Foreign Ministers of ASEAN Member States and China on The Full and Effective Implementation of The Declaration on The Conduct of Parties in The South China Sea. 2017. http://asean.org/storage/2016/07/Joint-Statement-on-thefull-and-effective-implementation-of-the-DOC-FINAL.pdf diakses pada 1 Maret 2017

Dokumen Kemenlu. 2010. Pernyataan Pers Tahunan Menteri Luar Negeri Republik Indonesia Dr. R.M. Marty M. Natalegawa. 
Muhammad Shuttle Diplomacy Indonesia di ASEAN Terkait Konflik Laut Naufal Aziz Tiongkok Selatan

Dokumen Kemenlu. 2014. Pernyataan Pers Tahunan Menteri Luar Negeri Republik Indonesia Dr. R.M. Marty M. Natalegawa

Dokumen Kementian Luar Negeri RI. 2013. Laut China Selatan https://www.kemlu.go.id/id/kebijakan/isu-khusus/Pages/LautChina-Selatan.aspx diakses 20 April 2018

Dokumen Statement on The Territorial Sea, The Contiguos Zone, The Exclusive Economic Zone, and The Continental Shelf of Vietnam. 1977. https://www.state.gov/documents/organization/58573.pdf , diakses pada 2 Februari 2017

Dokumen Statistical Information of Hunan. 2010. Report for Selected Countries and Subjects.

Dokumen U.S. Energy Information Administration. 2013. South China Sea.

Dokumen United States Department of State Bureau of Oceans and International Environmental and Scientific Affairs. 2005. Limits in the Seas 127.

E.W. World Economy Team. 2013. United States Economy

Emmerson, Donald K. 2017. Beyond the six points: how far will Indonesia go?, East Asia Forum, 29 Juli 2012 http://www.eastasiaforum.org/2012/07/29/beyond-the-six-pointshow-far-will-indonesia-go/ diakses pada 13 Juni 2017

Fravel, M. Taylor. 2011. "China's strategy in the South China Sea". Contemporary Southeast Asia. ISEAS.

Garver, John W. 1992. "China Push Through the South China Sea". The China Quarterly. 132

Glaser, Bonnie S.. Armed Clash in the South China Sea, Contingency Planning Memorandum No.14, April 2012, Center for Preventive Action.

Hanqin, Xue dalam Rodolfo C. Severino. 2010. "ASEAN and the South China”. Regional Security Journal 6. No.2.

Haryanto, Agus dan Arief Bakhtiar D. "Sengketa Laut Tiongkok Selatan: Ancaman Bagi Komunitas Keamanan ASEAN?". Jurnal Global \& Strategis. No.2.

Haryanto, Agus dan Arry Bainus. 2016. "National Role Conception of Indonesia in ASEAN: Natural Leader, Mediator, and 
Muhammad Shuttle Diplomacy Indonesia di ASEAN Terkait Konflik Laut

Naufal Aziz Tiongkok Selatan

Collaborator". International Journal of Public and Private Management 3. No. 2.

Haryo, Wahyudi Aditya. Peran dan Strategi Indonesia bersama ASEAN Dalam Upaya Meredakan Konflik Laut China Selatan.

Hoffman, David A. and Lily Hoffman-Andrews. 2013. Mediation and the Art of Shuttle Diplomacy.

Intentilia, Anak Agung Mia, D.A. Wiwik Dharmiasih, A.A. Bagus Surya Widya Nugraha, "Penyebab Kegagalan ASEAN dalam Penyusunan Code of Conduct Sengketa Laut Cina Selatan Selama Periode 2002-2012". Jurnal FISIP Universitas Udayana.

International Hydrographic Organization. 1953. Limits of Oceans and Seas, 3rd edition.

Iskandar. 2008. Metodologi Penelitian Penelitian dan Sosial (Kualitatif dan Kuantitatif). Jakarta:Gaung Persamda:186.

Isu Khusus Kementrian Luar Negeri Indonesia. 2018. Laut China Selatan, Kamis 28 Februari 2013, https://www.kemlu.go.id/id/kebijakan/isu-khusus/Pages/LautChina-Selatan.aspx diakses tanggal 22 Mei 2018.

Jenner, C.J., TranTruong Thuy. 2017. "The South China Sea: A Crucible of Regional Cooperation or Conflict-Making Sovereignty Claims?". Journal of Contemporary Asia.

Johnson, Kate Aubrey dan Helen Curtis. 2012. Making Mediation Work for You: A Practical Handbook, Legal Action Group.

Keyuan, Zou. "Scarborough Reef: A New Flashpoint in Shino-Philippine Relations?". Boundary and Security Bulletin Summer: 71-73

Keyuan, Zou. 2011. The Impact of Artificial Islands on Territorial Disputes Over The spratly Islands.

Kusumaatmadja, Mochtar. 1983. Politik Luar Negeri Indonesia dan Pelaksanaannya Dewasa Ini, Alumni Bandung.

Li, Mingjiang. 2014. "Mengelola isu keamanan di Laut China Selatan: Dari DOC ke COC". Center for South East Asian Studies. Jepang:Kyoto University

Liao, George. 2018. Scholar urges Taiwanese government to open Pratas Island to tourists, harian Taiwan News, 13 Agustus 2017, 
Muhammad Shuttle Diplomacy Indonesia di ASEAN Terkait Konflik Laut

Naufal Aziz Tiongkok Selatan

https://www.taiwannews.com.tw/en/news/3231452 diakses pada 18 Maret 2018

Luu, Chieu. 2017. Beijing criticizes Indonesia renaming part of South China Sea, harian online CNN, 15 Juli 2017, http://edition.cnn.com/2017/07/15/asia/indonesia-south-china-seaterritorial-claims/index.html, diakses pada 15 Agustus 2017

Marshall, Catherine dan Gretchen B. Rossman. 1999. Designing Qualitative Research 3e. California:Sage Publication Inc.

Mas'oed, Mochtar. 1990. Ilmu Hubungan Internasional Disiplin dan Metodologi. Jakarta: LP3ES

Masilamani, Logan dan Jimmy Peterson. 2014. "The“ASEAN Way": The Structural Underpinnings of Constructive Engagement" Foreign Policy Journal.

Mulyana, Deddy. 2001. Methodologi Penelitan Kualitatif. Bandung: PT. Remaja Rosdakarya.

Natalegawa, Marty. 2015. "Indonesia's deft diplomacy pays dividends". East Asia Forum.

Pedroza, Raul. 2014. "China versus Vietnam: An Analysis of the Competing Claim in the South China Sea". Center for Naval Analyses paper

Perlez, Jane. 2018. Vietnam Law on Contested Islands Draws China's Ire, harian online The New York Times, 21 Juni 2012, http://www.nytimes.com/2012/06/22/world/asia/china-criticizesvietnam-in-dispute-over-islands.html?_r=1 diakses pada 18 Maret 2018

Priatna, Ple. 2011. "Indonesia Tawarkan Mediasi Konflik ala ASEAN".Tabloid Diplomasi

Pudjiastuti, Tri Nuke dan Pandu Prayoga. 2015. "ASEAN dan Isu Laut Cina Selatan: Transformasi Konflik Menuju Tata Kelola Keamanan Regional Asia Timur". Journal Pusat Penelitian Politik 12. No.1.

Purnama, Crystal Liestia. 2017. Pertemuan ASEAN Bahas Kode Etik di Laut China Selatan, Harian Online Republika, 29 April 2017, http://internasional.republika.co.id/berita/internasional/global/17/ 04/29/op5af7368-pertemuan-asean-bahas-kode-etik-di-laut-cinaselatan diakses pada 14 Juni 2017 
Muhammad Shuttle Diplomacy Indonesia di ASEAN Terkait Konflik Laut Naufal Aziz Tiongkok Selatan

Qomara, Grienda. 2015. "Kebangkitan Tiongkok dan Relevansinya terhadap Indonesia”. Jurnal Hubungan Internasional VIII. No.2.

Raharjo, Sandy Nur Ikfal. 2014. "Peran Indonesia Dalam Penyelesaian Sengketa Laut Tiongkok Selatan”. Jurnal LIPI (Lembaga Ilmu Pengetahuan Indonesia).

Ritchie, Jane dan Jane Lewis. 2003. Qualitative Research Practice: A Guide for Social Science Students and Researchers. London:Sage Publication.

Sandi, Ayu Prima. Produksi Gas Blok Natuna Mayoritas Untuk Indonesia, harian online Tempo.co, 18 Mei 2013, https://bisnis.tempo.co/read/news/2013/05/18/087481348/produksigas-blok-natuna-mayoritas-untuk-indonesia

Sarith, Heng. 2013. "ASEAN: between China and America". Jurnal Cambodian Institue for Cooperation and Peace

Seiff, Abby. 2012. "Indonesian Foreign Chief to Arrive to Salvage Sea Dispute Talks". The Cambodia Daily. j

Sekretariat Nasional Asean. 1988. ASEAN - Selayang Pandang. Jakarta:Departemen Luar Negeri,

Shoji, Tomotaka. 2012. "Vietnam, ASEAN, and the South China Sea: Unity or Diverseness?". NIDS Journal of Defense and Security.

Sichun, Wu. 2014. Solving Disputes for Regional Cooperation and Development in the South China Sea: A Chinese Perspective, 2013, dalam Faudzan Farhana, "Memahami Perspektif Tiongkok Dalam Upaya Penyelesaian Sengketa Laut Cina Selatan”. e-journal LIPI

Sudira, I Nyoman. 2015 . "Konflik Laut China Selatan dan Politik Luar Negeri Indonesia ke Amerika dan Eropa”. Journal HI Unpar. Bandung:Universitas Parahyangan

Sugianto, Danang. 2018. 3 Tahun Illegal Fishing Diberantas, Potensi Ikan di Natuna Melejit, Detik Finance, https://finance.detik.com/berita-ekonomi-bisnis/d-3692146/3tahun-illegal-fishing-diberantas-potensi-ikan-di-natuna-melejit diakses pada 28 Mei 2018

Sukma, Rizal. 2017. ASEAN dan Sengketa Laut China Selatan, Kompas.com, http://internasional.kompas.com/read/2012/04/11/02542066/ASEA N.dan.Sengketa.Laut.China.Selatan diakses pada 13 Juni 2017 
Muhammad Shuttle Diplomacy Indonesia di ASEAN Terkait Konflik Laut

Naufal Aziz Tiongkok Selatan

Susilo Bambang Yudhoyono. 2009. Pidato Pelantikan. Jakarta (Oktober)

Susskind, Lawrence dan Eileen Babbit. 1992. "Overcoming the Obstacles to Effective Mediation of International Disputes" in Mediation in International Relations : Multiple Approaches to Conflict Management, ed. Jacob Bercovitch, Jeffrey Z. Rubin. London:Macmillan Press Ltd.

Szep, Jason dan James Pomfret. 2012. Tensions flare over South China Sea at Asian summit. Reuters

Thao, Nguyen Hong. 2012. Vietnam's Position on the Sovereignty over the Paracel \& the spratlys: Its Maritime Claims, Journal of East Asia International Law V.

Thayer, Carlyle A. 2012. "ASEAN Unity Restored by Shuttle Diplomacy?”. Thayer Consultancy

Thayer, Carlyle A. 2013, South China Sea Inregional Politics: Indonesia's Efforts to Forge ASEAN Unity on a Code of Conduct. CSIS (Juni).

Thuy, Tran Truong. 2011. "Recent Developments in the South China Sea: Implications for Regional Security and Cooperation". CSIS Policy Consultation on Maritime Security in the South China (Juni)

Trisni, Sofia, Apriwan \& Poppy Irawan. 2016. "Strategi Indonesia dalam Merespon Kebangkitan Tiongkok pada Masa Kepemimpinan Presiden SBY”. Andalas Journal of International Studies 5. No 2.

Tsirbas, Marina. 2017. Saving the South China Sea Fishery: time to internationalise. Asian National University (ANU) Policy Options Paper.No.03. (Juni).

Wang, Vincent Wei-cheng dan Chyungly Lee. 2014. ASEAN and Recent Tensions in the South China Sea.Virginia:University of Richmond press.

Westcott, Ben. 2017 Philippines vs China: Why the South China Sea ruling may change Asia, harian online CNN, 12 Juli 2016, http://edition.cnn.com/2016/07/04/asia/south-china-sea-un-caseexplainer/index.html diakses pada 15 Agustus 2017

Widhawaty, Muflichah Tri Hayu. 2016. Pendekatan Amerika Serikat Terkait Penyelesian Lauth China Selatan Pada Masa 
Muhammad Shuttle Diplomacy Indonesia di ASEAN Terkait Konflik Laut

Naufal Aziz Tiongkok Selatan

Pemerintahan Pertama Barrack Obama (2009-2013), Surabaya:Universitas Airlangga.

Wirasuta, Dadang. 2013. "Keamanan Maritim Laut Cina Selatan". Jurnal Pertahanan 3. No.3.

Zhou Enlai's Elected Works on Diplomacy. 1990. Beijing: Zhongyang wenxian chubanshe.

\section{Deklarasi Kepentingan yang Bertentangan}

Penulis menyatakan tidak ada potensi konflik kepentingan sehubungan dengan kepengarangan dan / atau publikasi artikel ini.

\section{Pengakuan}

Penulis mengucapkan terima kasih atas arahan dan bimbingan dari Pembimbing 1 (Anita Afriani Sinulingga, S.IP, M.Si) dan Pembimbing 2 (Sofia Trisni, S.IP, MA (IntRel))

\section{Biografi}

Muhammad Naufal Aziz merupakan alumni dari jurusan Ilmu Hubungan Internasional Universitas Andalas. Minat penelitiannya adalah tentang Diplomasi dan Laut Cina Selatan. Penulis dapat dihubungi melalui email:naufaalaziz18@gmail.com 